УДК 78.071.2

DOI $10.15421 / 22187$

Коротенко Дарія Валеріївна, кандидат історичних наук, доиент кафедри „Сочіально-гуманітарні дисиипліни” Дніпропетровської академії музики ім. М. Глінки

тел. (096) 727 - 44 - 48 e-mail: k-darii@ukr.net

\title{
ДО ПИТАННЯ ПРО ВПЛИВ ТОТАЛІТАРНОГО РЕЖИМУ НА МУЗИЧНУ СФЕРУ (на прикладі радянської культури 30-х років XX ст.)
}

Мета статті - проаналізувати особливості радянської музичної культури 1930-х років і ті трансформації, яким вона піддалась у зв'язку із втручанням тоталітарного політичного режиму. У роботі досліджується радянська музична культура 1930-х pp., а також вплив на неї з боку державного апарату та окремих діячів тоталітарної системи. Методологія грунтується на дослідницьких принципах системності, історизму, комплексному аналізі тенденцій у радянській музиці, взаємин мистецтва і влади. Структурно-аналітичний метод постав у основі логічного викладу матеріалу та написанні висновків дослідження. Наукова новизна полягає у визначенні ключових особливостей та конкретних механізмів впливу тоталітарного режиму на музичну культуру 1930-х pp., а також причин та наслідків впровадження єдиного стилю „соціалістичного реалізму” в музичному мистецтві. Висновки. У результаті застосування адміністративних заходів i прямого насильства стосовно діячів мистецтва значно постраждали стильова i жанрова різноманітність радянської музики, композитори були вимушені діяти 3 урахуванням розпливчатих вимог влади, а багато видатних творів залишились маловідомими масовому слухачеві. Особливістю державної політики стала, передусім, боротьба із напрямами і течіями в музиці, які не підпадали під вимоги соціалістичного реалізму (простіше кажучи, були незрозумілі чиновникам від культури). До арсеналу методів входили заборона виконання твору, цькування композиторів у 
пресі, в тому числі центральній. Репресії стосовно композиторів застосовувались рідше, ніж у інших сферах культури. У той же час твори, які відповідали вимогам партії і смакам масової аудиторії, отримували значну державну підтримку (наприклад, кіномузика, масова пісня). Слід підкреслити, що спільнота композиторів півтора десятиріччя протистояла впровадженню адміністративної вертикалі управління у вигляді відповідної всесоюзної організації.

Ключові слова: тоталітарна ідеологія, контроль над мистецтвом, радянська музична культура, формалізм, соціалістичний реалізм, „непролетарська” музика.

Коротенко Дария Валерьевна, кандидат исторических наук, доцент кафедры „Социально-гуманитарные дисциплины” Днепропетровской академии музыки им. М. Глинки

К вопросу о влиянии тоталитарного режима на музыкальную сферу (на примере советской культуры 30-х годов ХХ ст.)

Цель статьи - проанализировать особенности советской музыкальной культуры 1930-х годов и те трансформации, которым она подверглась в связи с вмешательством тоталитарного политического режима. Исследуется советская музыкальная культура 1930-х гг., а также влияние на неё со стороны государственного аппарата и отдельных деятелей тоталитарной системы. Методология базируется на исследовательских принципах системности, историзма, комплексном анализе тенденций в советской музыке, взаимоотношений искусства и власти. Структурно-аналитический метод лег в основу логического изложения материала и написания выводов исследования. Научная новизна заключается в определении ключевых особенностей и конкретных механизмов влияния тоталитарного режима на музыкальную культуру 1930-х гг., а также причин и последствий внедрения единого стиля „социалистического реализма” в музыкальном искусстве. Выводы. В результате применения административных мер и прямого насилия в отношении деятелей искусства значительно пострадало стилевое и жанровое разнообразие советской музыки, композиторы были вынуждены действовать с учётом расплывчатых требований власти, а многие выдающиеся произведения остались малоизвестными массовому 
слушателю. Особенностью государственной политики стала, прежде всего, борьба с направлениями и течениями в музыке, не подпадающими под требования социалистического реализма (проще говоря, были непонятны чиновникам от культуры). В арсенал методов входили запрет исполнения произведения, травля композиторов в прессе, в том числе центральной. Репрессии в отношении композиторов применялись реже, чем в других сферах культуры. В то же время произведения, которые отвечали требованиям партии и вкусам массовой аудитории, получали значительную государственную поддержку (например, киномузыка, массовая песня). Следует подчеркнуть, что сообщество композиторов полтора десятилетия противостояло внедрению административной вертикали управления в виде соответствующей всесоюзной организации.

Ключевые слова: тоталитарная идеология, контроль над искусством, советская музыкальная культура, формализм, социалистический реализм, „непролетарская” музыка.

Korotenko Dariya, $\mathrm{PhD}$ in historical science, associated professor of the „Social and humanitarian disciplines” chair, Dnipropetrovsk Music Academy after Mikhail Glinka

To the question about the influence of the totalitarian regime on the musical sphere (on the example of Soviet culture from the 1930s of the $20^{\text {th }}$ century)

The purpose of the article is to analyze the peculiarities of the Soviet musical culture of the 1930s and transformations which it suffered causing by interaction with the totalitarian political regime. The Soviet musical culture of the 1930s and the impact on it from the side of state apparatus and individual figures of the totalitarian system are being studied. The methodology is based on the research principles of systemicity, historicism, a comprehensive analysis of trends in Soviet music and the relations between art and power. The structural and analytical method was the basis of the logical presentation of the material and the writing of the conclusions of the study. The scientific novelty consists in determining the key features and specific mechanisms of the influence of the totalitarian regime on the musical culture of the 1930s, as well as the causes and consequences of introducing a unified style of ,socialist realism" in musical art. 
Conclusions. As a result of the use of administrative measures and direct violence against artists, the stylistic and genre diversity of Soviet music suffered dramatically; composers were forced to act with a look at the vague demands of the authorities, and many outstanding works remained little known to the mass audience. The peculiarity of state policy was, first of all, the struggle with trends and currents in music, which did not fall under the requirements of socialist realism (in other words, were incomprehensible to officials in the field of culture). The arsenal of methods included a ban on the execution of the work, the persecution of composers in the press, including the central one. Repressions against composers were used less frequently than in other areas of culture. At the same time, works that met the party's requirements and the tastes of the mass audience received significant state support (for example, cinema music and mass song). In article emphasized that the composer's community for one and a half decades opposed the introduction of an administrative management vertical in the form of all-union organization.

The key words: totalitarian ideology, control over arts, Soviet musical culture, formalism, socialist realism, „,non-proletarian” music.

Постановка проблеми. Політика у сфері культури, яку проводив тоталітарний сталінський режим, лишається у полі уваги дослідників різних наукових галузей. Встановлюючи жорсткі ідеологічні межі, застосовуючи адміністративні заходи та репресії, правляча партія перетворила радянське мистецтво на зручний інструмент впливу на суспільство. При цьому керівництво мистецтвом здійснювали „професійні революціонери” без необхідних знань, які не мали уявлення про сутність процесу творчості. Це й визначило трагедію митців, які змушені були працювати у таких умовах, але не хотіли чи не могли пристосуватись до вимог держави.

Актуальність дослідження. Політична ситуація 1930-х років значно вплинула на розвиток радянської культури, а через неї - i на національні культури пострадянського періоду. У сучасному суспільстві небезпека встановлення тоталітарних режимів зберігається постійно, особливо у зв'язку із важкою геополітичною ситуацією для України сьогодні, i тому необхідно навчитись вчасно 
розпізнавати ознаки надмірного втручання держави у культурну сферу.

Огляд літератури. Вивчення тоталітарної культури періоду сталінських репресій 1930-х років, що почалось після розпаду СРСР, продовжується разом із освоєнням масиву раніше недоступних джерел (щоденників, листів діячів культури, таємних державних документів тощо), що відображають глибинні процеси в культурній сфері, взаємини діячів культури між собою та 3 владою. При цьому пострадянські дослідники переважно фокусують власну увагу на подробицях взаємодії держави і культури (наприклад, робота Є. Дорохової), а західні (К. Брук, Н. Едмундс) намагаються сформулювати основні тенденції радянської культурної політики, 3'ясувати вплив ідеологічно забарвленої музики на суспільство.

Мета статті - проаналізувати особливості радянської музичної культури 1930-х років у світлі тих трансформацій, яким вона піддавалась у зв'язку із втручанням тоталітарного політичного режиму.

Об'сктом дослідження постає радянська музична культура 1930-х років, а предметом - вплив на радянську музичну культуру з боку державного апарату та окремих діячів тоталітарної системи.

Виклад основного матеріалу. Тоталітарна система, як писав французький історик мистецтва Ф. Серс, базується на роздробленні суспільства (знищенні традиційних зв'язків між людьми) і формуванні єдиної партії, яка спирається на ідеологію. Ідеологія, за Альтюссером, дослідником ідеологічних апаратів держави, представляє собою систему уявлень, в якій соціально-практична функція переважає над пізнавальною, теоретичною $[8,30]$. Мистецтво в умовах тоталітарної держави позбавлене можливості трансформувати суспільство, воно покликане ілюструвати політику, прийняту без його участі. Трагедія полягає в тому, що не всі діячі мистецтва здатні виконувати цю роль. Сильні особи, оригінальні творці (якими були представники музичного авангарду) вступають у конфлікт із тоталітарною системою, спрямованою, перш за все, на знецінення особи. Вони не можуть прийняти нового стану речей, при якому канон у мистецтві - більше не результат консенсусу, а чиє-небудь особисте рішення $[8,50]$.

Втім, тотальний партійно-державний контроль торкнувся музичної сфери лише у другій половині 1920-х років. Одразу після 
громадянської війни музичному співтовариству було властиво, швидше, самообмеження, викликане пошуками нового в мистецтві. Вже у Декларації Музичного відділу Наркомпроса РРФСР (березень 1919) заявлялось, що первинні початки музики містяться у народній пісні. Вона протиставляється „формальносхематичному" стану музичного твору. Високі звукові інтонації потребують звільнення від „помилкових канонів” i „правил музичної схоластики" [2, 136]. Декларація Асоціації пролетарських музикантів (1923) ще категоричніша. У ній йдеться про необхідність вироблення марксистської лінії в підході до музичного мистецтва, застосуванні класового критерію при виданні музичних творів. Автори Декларації підкреслюють наявність двох небезпек розчинення у середовищі „композиторів, що естетствують”, або ж розтрачування таланту на „випадкові досліди” революційної творчості, не регульовані класовою свідомістю [2, 137]. Тоталітарні риси простежуються у положеннях програмного документа фракції червоної професури Московської консерваторії, де вимагалось позбутися принципу „мистецтво заради мистецтва” та викорінити уявлення про музикантів, як про позакласових „жерців” музики $[2,138]$. Ідеологічна платформа Всеросійської асоціації пролетарських музикантів засуджувала „непролетарську” музику, в якій відбувається розмежування музики за формальними ознаками (напрямами), а зміст втрачається, відриваючись від форми. Внаслідок цього буржуазна культура вироджується, що виявляється у бідності метрорітмічного малюнку, захопленні ,алогічними, судорожними" ритмами [2, 139-140].

Суперечка про те, якою повинна бути музика нового часу і що потрібно від радянського композитора, достатньо яскраво відображає стаття Л. Калтата „О подлинно буржуазной идеологии гр. Н. Рославца”. Композитор М. Рославець торкнувся питання про слабкі сторони пролетарської музики. На його думку, ясна і проста музика базується на зумисно примітивних „музичних організмах”, вимагає мінімуму музичних засобів i композиторської винахідливості. Л. Калтат заперечував, що композитор пише „ясно і зрозуміло", коли щиро виражає емоцію. Саме через емоційну частину людини музика здійснює свою ідеологічну дію. Футуристична ж музика страждає на схематичність, шаблонність, позбавлена емоційності (або ж емоції нагадують істерику). 
М. Рославець вважав, що пролетаріат не повинен створювати власну музику на основі форм, що виникли 3 національнопобутових умов селянства. Л. Калтат, у свою чергу, цитував сталінську формулу щодо національної форми і пролетарського змісту культури і стверджував, що пролетаріат прагне не тільки до політичної, але й до культурної диктатури [3, 318-323].

У 1920-х роках провідні музичні організації були представлені Російською асоціацією пролетарських композиторів (РАПМ), Об'єднанням революційних композиторів i музичних діячів, а також Виробничим колективом студентів-композиторів Московської консерваторії (Проколл). Остання організація виступила із колективним ювілейним твором „Путь Октября” (1927) [10, 106-112]. Тоді ж з'являються такі зразки пропагандистської музики, як опера „Красный Петроград” А. Гладковського і Е. Пруссака (1925), „Деревенская симфония” й кантата „1905 год” О. Кастальського.

У 1930-х роках до музичної творчості починають повною мірою застосовувати поняття партійності в сенсі ,злиття з ідеями партії Леніна-Сталіна, з теорією комунізму" [2, 151]. Спроби встановлення державного тотального контролю над музичною сферою почались ще у 1932 р., коли в квітневій ухвалі ЦК партії щодо союзу радянських письменників були згадані й інші види мистецтва. У травні того ж року була ліквідована РАПМ. Проте створення всесоюзної музичної організації затягнулось на 16 років. Змінились три склади оргкомітетів, покликаних створити союз. Навіть спеціальна ухвала Політбюро, видана у травні 1939 р., по суті, не була виконана [6, 24-31].

Тим часом тоталітарний сталінський режим знаходив інші інструменти для керівництва музичною сферою мистецтва. Так, у серпні 1933 р. вийшла ухвала про репертуар на грамофонних платівках (симфонічна музика, народні пісні, художнє читання, романси, арії, танцювальна музика) і платню виконавців (залежно від тиражу платівки) [6, 33-36]. Не менш важливою можна вважати директиву від 23 жовтня 1932 р., якою постановка певних п’єс (зокрема, опер) розповсюджувалась на весь СРСР (під виглядом демонополізації репертуару) [6,41]. У 1935 р. була створена внутрішня (секретна) комісія зі спостереження за діяльністю державних театрів, а у 1936 р. - Комітет у справах мистецтв при 
уряді. КСМ у 1936 - 1938 рр., тобто, в епоху найбільшого за розмахом терору, очолював П. Керженцев [6, 46-57]. Під його керівництвом здійснювалась і кампанія з боротьби із формалізмом у музиці. Старт кампанії був започаткований редакційною (без підпису) статею в „Правде” від 28 січня 1936 р., названою „Сумбур вместо музыки”. Спрямована проти опери Д. Шостаковича „Леди Макбет Мценского уезда", стаття рясніла негативними виразами: „нестрункий, сумбурний потік звуків”, спів ,замінений криком”, музика „умисне зроблена навпаки”. Прямо заявлялось, що композитор „зашифрував власну музику”, щоб зробити іiі доступною лише для „,естетів-формалістів, що втратили здоровий смак” [7, 5-7]. Пізніше, у ході кампанії 1948 р., офіційно було заявлено, зокрема А. Ждановим, що стаття у „Правді” була інспірована ЦК й відтворювала його позицію [6, 109-110].

Незабаром після появи статті у пресі Д. Шостакович зустрівся 3 П. Керженцевим і отримав від нього ряд рекомендацій, які мали сприяти виправленню композитора (втім, вони так і не були виконані). Серед них: зробити поїздку по СРСР і відібрати сто кращих народних пісень, надсилати лібретто майбутніх опер i балетів на перевірку в КСМ, а також влаштовувати в процесі роботи прослуховування їх окремих частин у колективах робітників і колгоспників [6, 111-112].

Показово, що Д. Шостаковича публічно звинувачували у тому, що він пише музику „про запас”. Це нібито свідчило про аполітичність його творів, що вже само собою було звинуваченням. Музика позбавлена ідейності, партійності, народності й програмності автоматично ставала „сумбуром” [6, 137-138].

На захист композитора виступив письменник М. Горький. У чернетці листа Сталіну він відзначав, що критика опери Д. Шостаковича недоказова i завдає шкоди композиторові, який заслуговує дбайливого ставлення як найбільш обдарований радянський музикант [1,300-302]. Згідно із даними держуправління держбезпеки НКВС СРСР, низка діячів культури в приватних бесідах висловлювали підтримку Д. Шостаковичу i побоювались посилення контролю над мистецтвом. Серед них: Ю. Олеша, I. Бабель, I. Сельвінський, П. Антокольський, В. Шкловський, Ю. Яновський, А. Платонов, В. Мейєрхольд, а також композитори В. Держановський, М. Мясковський, 
Ю. Шапорін, М. Кочетов, Л. Синявер i головний диригент Великого театру М. Голованов.

Так, композитор М. Мясковський побоювався панування в музиці убогості й примітивності. У свою чергу, драматург А. Платонов вважав рішення щодо опери ,розносом” кого-небудь 3 „вельми сильних”, хто нічого не розуміє в музиці [1, 290-295].

Протягом кампанії у березні 1936 р. відбулась нарада, присвячена названому твору Д. Шостаковича. Державний i суспільний діяч П. Керженцев озвучив гасло створення радянської класичної опери. На його думку, їй повинні були бути властиві такі характеристики, як доступність, масовість, історична правдивість, а також „відсутність формалістичних або грубо-натуралістичних вивертів". Встановлювалась цензура у вигляді попереднього ознайомлення 3 лібретто, а також подальших переглядів (прослуховувань) [6, 123-125]. Серед гучних заборон у подальшому можна назвати опери „Великая дружба” (1948р.) й „Декабристы” (1953 р.). Заборонена була також опера-фарс „Богатыри” Бородіна на лібретто Демьяна Бідного. Вона включала фрагменти музичних творів Верді, Кавоса, Оффенбаха, Россіні тощо [6, 215].

Подібна ситуація виявлялась у „мовчазній змові” формалістів, цехових забобонах музикантів, „музичному дворушництві” композитора Б. Асафьєва (що писав доступну музику, але „сповідував” формалізм) [1,302-304]. У результаті виникли два види заборон: висхідний (ініціатива виходить від КСМ) та нисхідний (явковий), обумовлений втручанням членів ЦК або Сталіна особисто [6, 214].

3 великою увагою тоталітарна влада ставилась і до кіномузики. Той же Д. Шостакович був автором музики до класичних сталінських фільмів. Це, в першу чергу, „Встречный” (1932), пісня 3 якого використовувалась навіть за кордоном (французький фільм „Життя належить нам” 1936 р. та американський - „Thousand cheer” 1943 р., де пісня звучить під назвою „United nations on the march”). Д. Шостакович написав також музику до фільмів „Выборгская сторона” i „Человек с ружьем" $[4,76]$. Зразково-показовою 3 погляду виконання ідеологічного завдання має вигляд його музика до фільму „Великий гражданин” (1937) про вбивство більшовика троцькистами (мався на увазі С. Кіров). 
Кіномузика покликана була акцентувати увагу на цінностях, проголошених у радянському суспільстві. Це, в першу чергу, трудовий ентузіазм і творчий пафос. Розквіт кіномузики багато в чому пояснюється державною підтримкою. Так, у 1936 р. за клопотанням О. Косарєва й Б. Шумяцького до Сталіна, композиторові I. Дунаєвському було присуджено звання заслуженого діяча мистецтва за марші з фільмів „Веселые ребята” (в основу пісні лягла мексиканська народна мелодія „La Adelita”), „Цирк”, „Путь корабля” і „Три товарища” („Каховка”) [6, 166]. Це рішення вплинуло на статус кіномузики і привернуло композиторів до роботи над масовою піснею. Втім, лідерство залишалось за тим же I. Дунаєвським, який за 8 років написав музику до 18 фільмів $[11,36]$. Цікаво, що у цьому випадку влада ставилась терпимо до джазу, який, як відомо, вважався „музикою занепаду”.

Таким чином, у радянській музиці, як і в мистецтві взагалі, єдино можливим стилем став „соціалістичний реалізм”. Така музика, на думку Л. Геллера, мала демонструвати ідеологічну прихильність (підпорядкованість розвитку центральної ідеї), партійне мислення й національний (народний) дух [12, 22].

Подібні розпливчаті вимоги вели до того, що окремі твори могли перероблятись роками й так і не дійти до широкої публіки. Прикладом може слугувати „Ленинская кантата” С. Прокоф'єва.

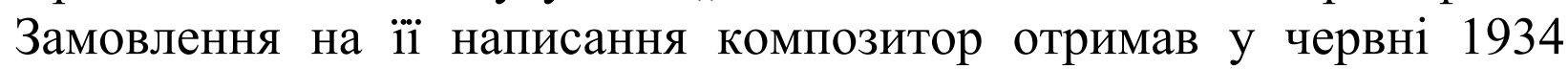
року. За умовами, кантату тривалістю 25-35 хвилин мав виконувати хор і симфонічний оркестр. Крім того, від твору була потрібна радіофонічність, дотримання „правильної і чіткої” політичної настанови, а також художніх вимог $[5,83]$. Відповідно до задуму композитора, у кантаті повинні були звучати цитати 3 творів Леніна, що і стало каменем спотикання. Критиці піддався як підбір цитат, так і те, що деякі слова у них були змінені. С. Прокоф’єв перейменував твір, назвавши його „К двадцатилетию Советской революции", була додана промова Сталіна від 24 січня 1924 року, до професійного хору був доданий самодіяльний, задіяний оркестр народних інструментів.

Під впливом ухвалення „Сталінської” конституції СРСР у грудні 1936 р. С. Прокоф'єв знов переробив кантату, долучивши туди промову Сталіна від 25 листопада 1936 р., а також додавши чотири інструментальні частини. $\mathrm{У}$ результаті загальний 
хронометраж зріс до 45 хвилин, а назва стала остаточною „Кантата к двадцатилетию Октября”. Проте і в такому вигляді на закритому прослуховуванні у червні 1937 р. твір отримав переважно негативну оцінку й не тільки не був виконаний до двадцятиріччя революції, але і не виконувався ще 28 років (до квітня 1966 р.). Фрагменти кантати С. Прокоф'єв використовував у симфонічній музиці - „Ода до закінчення війни” (1945) [5, 85-96].

На думку К. Брук, зміни у сталінській музичній політиці були викликані стахановським рухом (що розгорнувся 31935 р.), оскільки на культурний сектор розповсюджувались вимоги до підвищеної продуктивності праці. Влада також чекала, що мистецтво зуміє підняти культурний рівень робітників. До того ж, коли справи у промисловості налагоджувались, влада змогла сфокусувати увагу й на культурі $[12,24]$.

Хоча й на діячів музики виявлявся безпрецедентний тиск, фізичній розправі вони піддавались порівняно рідко. Можна погодитись із К. Брук, що більшість жертв „Великого терору” в музичній сфері були швидше адміністраторами, а не практикуючими музикантами. Так, не тільки професійна діяльність, але й дружба 3 маршалом Тухачевським не привели до арешту Д. Шостаковича. Проте були арештовані його теща - С. Варзар, чоловік сестри - В. Фредерікс. Можливо, композитори менше постраждали від репресій, тому що схильні були захищати, а не обмовлювати колег. Так, Р. Глієр та М. Мясковський у березні 1938 р. написали Калініну лист на захист арештованого композитора О. Мосолова, і домоглись його звільнення. Можливо також, що влада цінувала композиторів, оскільки музика розглядалась як засіб поліпшення міжнародних відносин $[9,406-$ 410].

Висновки. Сталінський тоталітарний режим грубо втручався у процес створення музики, встановлюючи жанрові й стилістичні рамки творчості, переслідуючи композиторів за надуманими приводами, заохочуючи пропагандистські твори. Обмежуючі адміністративні заходи, а також репресії завдали непоправної шкоди музичній культурі радянського періоду. Багато талановитих творів десятиліттями були недоступні для масового слухача. Розвиток музики, творчий пошук були фактично законсервовані. Багато в чому епоха репресій показова тим, що у першу чергу, 
тоталітарна система бореться саме 3 проявами інакомислення у культурній сфері.

Що важливо пам'ятати сьогоднішньому поколінню молодих $\mathrm{i}$ талановитих музикантів? Культура - й елітарна, і побутова залежна від політичної ситуації, як би не намагались абстрагуватися від цього діячі мистецтва. У зв'язку 3 цим, актуальним $є$ синтез музичної та соціальної сфери в побудові сучасного громадянського суспільства, створенні й функціонуванні полікультурного українського соціуму.

Перспективи дослідження полягають у подальшому вивченні надбання радянських композиторів, яке було втрачене для сучасників, визначенні альтернативних шляхів розвитку мистецтва, які були започатковані, але не дістали розвитку за радянської доби.

\section{Список використаних джерел і літератури:}

1. Власть и художественная интеллигенция (1917-1953). Москва: МФД, 1999. $872 \mathrm{c}$.

2. Ганжа А. Советская музыка как объект сталинской культурной политики // Логос. Москва, 2014. Вып. 2 (98). С. 123-155.

3. Гойови Д. Новая советская музыка 1920-х годов. Москва: Композитор, $2005.368 \mathrm{c.}$

4. Демченко А.И. Концептуальный потенциал искусства. Музыкальноисторический этюд на материале 1930-х годов // Искусство и культура. Київ, 2016. Вип. 4. С. 70-80.

5. Дорохова Е. „Кантата к двадцатилетию Октября” С. Прокофьева: история создания // OPERA MUSICOLOGICA. Москва, 2011. Вып. 1. С. 77-98.

6. Максименков Л.В. Сумбур вместо музыки. Сталинская культурная революция (1936 - 1938). Москва: Юридическая книга, 1997. 320 с.

7. Против формализма и натурализма в искусстве. Москва: ОГИЗ-ИЗОГИЗ, 1937. $79 \mathrm{c}$.

8. Серс Ф. Тоталитаризм и авангард. Москва: Прогресс-Традиция, 2004. $336 \mathrm{c}$.

9. Brooke C. Soviet Musicians and the Great Terror // Europe-Asia Studies. London, 2002. Vol. 54. P. 397-413.

10. Edmunds N. Soviet Music and Society under Lenin and Stalin. London, New York: Routledge, 2004. 256 p.

11. Egorova T. Soviet Film Music: Historical Survey. London: OPA, 1997. $326 \mathrm{p}$. 
12. Smrz J. Symphonic Stalinism: claiming russian musical classics for the new soviet listener. Munster: Lit, 2011. 187 p.

\section{References:}

1. The Regime and Intelligentsia of Art (1917-1953), (1999). Moskva: MFD [in Russian].

2. Ganzha, A. (2014). Soviet Music as an Object of Stalinist Cultural Policy. Logos, 2 (98), 123-155 [in Russian].

3. Goyovi, D. (2005). New Soviet Music of 1920s. Moskva: Izdatelskiy Dom „Kompositor” [in Russian].

4. Demchenko, A. (2016). Conceptual Potential of Art: Musical and Historic Sketch on the Material of the 1930s. Iskusstvo i kul'tura, 4, 70-80 [in Russian].

5. Dorokhova, Y. (2011) „The Cantata for the 20th Anniversary of the October Revolution" by Sergei Prokofiev: history of creation. OPERA MUSICOLOGICA, 1, 77-98 [in Russian].

6. Maksimenkov, L. (1997). Muddle Instead of Music. Stalinist Cultural Revolution, 1936-1938. Moskva: Juridicheskaja kniga [in Russian].

7. Against Formalism and Naturalism in Art (1937). Moskva: OGIZ-IZOGIZ [in Russian].

8. Sers, P. (2004). Totalitarianism and avant-garde. Moskva: Progress-Tradicija [in Russian].

9. Brooke, C. (2002). Soviet Musicians and the Great Terror. Europe-Asia Studies, 54, 397-413 [in English].

10. Edmunds, N. (2004). Soviet Music and Society under Lenin and Stalin. London, New York: Routledge [in English].

11. Egorova, T. (1997). Soviet Film Music: Historical Survey. London: OPA [in English].

12. Smrz, J. (2011). Symphonic Stalinism: Claiming Russian Musical Classics for the New Soviet Listener. Munster: Lit [in English]. 